\title{
Informal Settlements and Flooding: Identifying Strengths and Weaknesses in Local Governance for Water Management
}

\author{
David Samuel Williams ${ }^{1, *(1)}$, María Máñez Costa ${ }^{1}$ (D), Louis Celliers ${ }^{1}$ (D) \\ and Catherine Sutherland ${ }^{2}$ \\ 1 Climate Service Center Germany (GERICS), Helmholtz-Zentrum Geesthacht, 20095 Hamburg, Germany; \\ maria.manez@hzg.de (M.M.C.); louis.celliers@hzg.de (L.C.) \\ 2 School of Built Environment and Development Studies, University of KwaZulu Natal, \\ Durban 4041, South Africa; sutherlandc@ukzn.ac.za \\ * Correspondence: david.williams@hzg.de
}

Received: 30 March 2018; Accepted: 27 June 2018; Published: 29 June 2018

\begin{abstract}
Urbanization and climate change are compounding the vulnerability of flooding for the urban poor, particularly in the Global South. However, local governance can be a greater determinant of flood risk than the hazard itself. Identifying strengths and weaknesses in local governance for water management is therefore crucial. This paper presents a governance assessment for Quarry Road West informal settlement, Durban, South Africa, in relation to flood risk by applying the Capital Approach Framework. Through developing a deeper understanding of the current governance system, the embeddedness of several social values can also be gauged. This is important particularly for integrative and transdisciplinary management of flood risk, enacted in the case of Quarry Road West informal settlement through the Palmiet Rehabilitation Project, a multi sector partnership at the climate change and water governance interface. Findings from this study indicate that, currently, climate change adaptation remains a challenge for decision-makers and policy-planners. A more effective integration of the residents of Quarry Road West informal settlement into local governance for water management is urgently needed. This is particularly important in the context of informal settlements that are marginalized and often lacking governance mechanisms to affect change.
\end{abstract}

Keywords: water governance; multi-sector partnerships; flooding; informal settlements

\section{Introduction}

Currently, half of the world's population lives in cities and by 2050, the global level of urbanization is predicted to rise to $70 \%$ [1]. The speed of urbanization is resulting in extreme challenges for the sustainability and prosperity of cities [2]. The urban poor, not only characterized by low income levels, but by poor quality and over-crowded housing, lack of secure tenure, insufficient access to safe water supplies and sanitation, drainage and solid waste collection, as well as healthcare, emergency services and policing, and commonly located in environmentally vulnerable areas, are those most at risk from the effects of climate change [3]. As a result of urban poverty, rapid urbanization, the decompression of existing poor and crowded urban settlements, and the inability of the state or the market to provide affordable housing for the urban poor, over 1 billion people reside in informal settlements, primarily across the Global South. The high level of dichotomy between the conceptual framing of informal settlements, urban poor, and urban resources confounds the ability to define the relation between these concepts unambiguously [4]. The understanding taken in this study is that informal settlements are most commonly resided in by the urban poor, and are usually located on marginal 
land in the inner core of cities, where the urban poor can gain improved access to urban resources such as healthcare, emergency services, policing or education through governmental schools, or on the periphery of cities, where land is available [5].

At the same time, climate change is affecting the frequency, intensity, and predictability of environmental risk $[2,6]$. Cities are particularly vulnerable to the effects of climate change due to the combination of increased precipitation, storm events and floods, extended periods of decreased precipitation and drought events, prolonged stages of intense heat and cold, and rising sea levels. Social vulnerability is commonly concentrated in hazard-prone areas in the city and there is a growing insufficiency of urban infrastructure to cope with the impacts of climate change and protect the population. This highlights the necessity for risk-informed development of urban infrastructure such as road and rail transport, communications, water and energy to deal with the impacts of rapid urbanization and climate change [2].

Thus, the New Urban Agenda lists "enhancing urban resilience to climate change and disaster risks" as one of its key challenges for sustainable cities and communities [5]. However, cities also offer significant opportunities for addressing climate change through innovation, efficiencies and the potential for the appropriate governance of, and planning for, mitigation and adaption efforts. Population growth and spatial expansion are further exacerbating flood vulnerability for poor populations in many countries [7], transforming the relationship between bio-physical and social systems [8]. With poor housing and basic services compounding the risks for residents of informal settlements, increasing resilience in coastal cities experiencing rapid urbanization, particularly in tropical and subtropical regions where climate change impacts are more pronounced and difficult to predict, is a major challenge [1,9]. Presently, flood events account for over half of disaster-related fatalities and a third of economic loss resulting from all climate-induced risks [10]. The risk of flooding will further increase with global warming [11], affecting the hydrological cycle and posing an urgent climate-induced risk for vulnerable communities, particularly those residing in informal settlements across the Global South [12]. It is important to note, however, that although the physical extent of flooding episodes is increasing, research has found negative effects experienced by residents are more attributable to ineffective governance, rather than flooding itself [13].

While climate change is a global phenomenon, and is increasingly being recognized as such by various decision-makers and policy-planners [14], the response to climate-induced risks is predominantly local, which means that local governance is critical $[15,16]$. Local governance, defined as the "formulation and execution of collective action at the local level" [17], needs to focus on implementing policies and strategies which lessen the impacts of climate-induced risks on individuals and communities [16]. Local governance is carried out by formal institutions, as well as informal networks or partnerships, community organizations or neighborhood associations [17]. Effective local governance is determined not only by the provision of local services, but also depends on the preservation of life and well-being, creating the opportunity for democratic participation and dialogue, as well as supporting sustainable development [17]. It is therefore within the scope of local governance to manage climate-induced risk, including the reduction of existing risk, the avoidance of new disaster risk, and the management of residual risk $[16,18]$.

Developments in human distribution and climate change impacts, in particular changing precipitation patterns leading to increased flooding in coastal areas, illustrate the need for improving local governance for water management. Water can have various different ontologies, a threat or a border for some, a resource or an opportunity for others [19]. In this study, water is understood both as a dynamic external threat, and as an ecosystem providing vital services for local residents. The current research focus in local governance for water management has experienced a paradigm shift toward more integrated systems of managing climate-induced risk [13,20]. A single authority or agency is unable to provide effective governance dealing with the complex und multi-faceted nature of flood risk [21], understood in its simplest form as the probability of flooding multiplied by the potential loss 
or damage. Numerous national and international treaties on environmental issues acknowledge the requirement for stakeholder participation in decision-making and policy-planning [10,19].

In an effort to facilitate an inclusive and transdisciplinary approach to flood risk, some have suggested local governance needs to be enacted by multi-lateral partnerships, or "multi-sectoral partnerships", defined as "voluntary but enforceable commitments between public authorities, private enterprises, and civil society organizations across sectors. They can be temporary or long-lasting. They will be founded on principles of sharing the same goal in order to reduce risks and gain mutual benefit. (....) Partnerships involve a shift in governance structures and the implied acquisition of competencies typically derived from governmental structure" [22]. Multi-sectoral partnerships should enable mobilizing and sharing knowledge, expertise, technology and financial resources, as well as encourage and promote effective public, private-public and civil society partnerships [23]. The benefit of integrating these actors and processes in the form of multi-sector partnerships has been recognized by the United Nations General Assembly and is seen as a key means not only of reducing disaster risk within the Sendai framework, but also of achieving the Sustainable Development Goals [23,24].

Thus, effective local governance for water management is dependent upon the integration of a diverse range of stakeholders in participatory governance processes to co-produce knowledge. A grounded analysis of governance therefore needs to include, amongst others, local government, the private sector, scientists and the broader research community, and local communities.

Effective local governance is also dependent on the integration of mutually constructed social values, understood here as moral beliefs and principles ensuring the sustainable continuation of society [25]. Local governance should be shaped by social values, reflecting the importance, worth, desirability and respect of shared moral beliefs and principles [26]. Multi-sector partnerships are designed to integrate and to promote the co-construction of social values, addressing the need for a less hierarchical top-down approach to local governance for water management, using non-legislative instruments to complement policy tools, and encouraging new forms of governance, partnerships, greater participation and civil dialogue under guiding principles of transparency, openness, accountability, coherence and effectiveness [23]. Multi-sector partnerships range from formal, institutionalized legislative entities, to non-formal co-operations. In their simplest form, they describe any form of collaboration between state and non-state actors [27]. This is particularly important for informal settlements, as not only are these communities commonly excluded from formal urban planning processes. They also often do not adhere to the traditional school of top-down hierarchical governance, having been replaced by non-hierarchical governance in which non-state actors play a greater role in the formulation and implementation of public policy [28]. Thus, the inclusion of inherently marginalized informal settlement communities in local governance processes is a considerable challenge, and mechanisms encouraging their participation and amplifying their voice are needed.

Through the integration of stakeholders from various sectors, multi-sector partnerships are also inherently transdisciplinary. This is an important necessity, as single disciplinary approaches often fail in addressing intractable problems, and a range of knowledge, methodologies and learning needs to be considered for implementable sustainable solutions to environmental issues [29]. Transdisciplinarity can be viewed as an extension of interdisciplinarity, facilitating integration of disciplinary paradigms, and encouraging participation from a range of different stakeholders [19]. Transdisciplinarity is therefore not driven by disciplines themselves, rather by socially relevant issues, integrating civil society, private and public sectors [19].

Local governance for water management is increasingly integrative and transdisciplinary in nature. Much research has been carried out on the integration of social factors in analyses evaluating the effectiveness of multi-sector partnerships in formalized institutionalist governance structures $[23,24,27,30,31]$. There is however a lack of knowledge concerned with measuring the integration of social factors when evaluating multi-sector partnerships in non-formalized governance structures. Not only can multi-sector partnerships be a driver of transformative change and 
vehicles of development, they can also help reduce the climate-related risks, the burden of which is disproportionately carried by residents of the Global South. This also highlights the potential benefit of the ability to qualitatively assess multi-sector partnerships, contributing to a reduction in environmental risk for residents of informal settlements. However, previous research has found that the level of formalized institutionalism is a good indicator of the success of multi-sector partnerships [28]. With lack of formalized institutionalism and mainstream governance prevalent across the Global South, contributing to corruption, ineffective governance structures, and an absence of civil society $[1,13]$, the ability to assess the performance of multi-sector partnerships in the context of climate-induced natural risk in informal settlements, and the ability to measure the uptake of social values in local governance processes, may prove highly valuable.

The role of local communities in project planning and implementation is necessary not only to strengthen the capacity of local communities to adapt, but also in regard to the multi-level nature of adaptation policy and programming [32]. The success of multi-level governance is therefore dependent on the ability of generating adaptation strategies through participatory processes involving stakeholders from various sectors [32]. Previous research however indicates that adaptation efforts have commonly been undertaken through hierarchical top-down approaches, with little or no attention being given to how local communities experience the effects of climate change and carry out adaptation to changing environments [33].

Thus, the aim of this paper is to identify strengths and weaknesses of current local governance for water management in Quarry Road West informal settlement through the perception of the Palmiet Rehabilitation Project (PRP), a multi-sector partnership dealing with flooding in the catchment. This assessment should furthermore provide some insight into the uptake of social values into local governance processes, such as democratic participation, gender equality, or trusting relationships.

\section{Study Site}

Quarry Road West informal settlement in Durban, South Africa, is representative for many other informal settlements around the world. It was established in 1984 and is located in the urban core of Durban, or its administrative entity, eThekwini Municipality. Durban has a population of 3.6 million, making it the third largest city in South Africa [34]. With $41.8 \%$ of its inhabitants living in poverty, an unemployment rate of $16.5 \%$, and $27.4 \%$ of the city's residents living in informal settlements, Durban faces significant social, economic and political challenges [35-37]. Climate variability is further increasing, compounding the uncertainty of environmental futures and risk in the city [38].

Durban has a humid and subtropical climate, with warm, wet summers and mild, dry winters, due to the presence of the South Indian Anticyclone and coastal low-pressure systems moving from west to east along the coast. The Environmental Planning and Climate Protection Department (EPCPD) projects an increase in mean annual temperature of between $1.5^{\circ} \mathrm{C}$ and $2.5^{\circ} \mathrm{C}$ by 2065 , further increasing to between $3{ }^{\circ} \mathrm{C}$ and $5{ }^{\circ} \mathrm{C}$ by 2100 . Combined with a rise in maximum temperature, this is likely to cause a higher incidence of heat waves and droughts [38,39]. Mean annual precipitation exceeds $1000 \mathrm{~mm}$ per annum, making Durban one of South Africa's wettest cities [35]. A considerable change in precipitation events is projected as a result of climate change. The total amount of annual precipitation is set to rise by $500 \mathrm{~mm}$, which will fall in short, intense rain events, rather than in the longer periods of soaking rain previously experienced in the city. This is confirmed by the Climate Service Center Germany (GERICS), which has already observed an increase in intense rainfall, and a decrease in rain-days [40]. Overall, annual rainfall variability is expected to increase significantly $[38,39]$. This data suggests a pattern of increasing storm and high intensity rain events which will exacerbate surface water flow and flooding in the city. As environmentally stressed informal settlements are a common feature of the Durban landscape, the combination of sub-standard housing, poor services and increased rainfall and surface water flow creates significant risk for those living in these settlements. 
According to a survey carried out by the Community Organization Resource Centre, Quarry Road West informal settlement has a household size of 550, and a population of 1650 , indicating an average of just over three persons per household [36]. A community-based mapping project undertaken in July 2017 however revealed that there are 931 households in Quarry Road West informal settlement, with a population of approximately 2400 residents. Household size varies considerably with an average of just over three persons per household. It is a centrally located urban informal settlement in close proximity to residential suburbs, major transport routes and Durban's Central Business District. These resources provide opportunities for informal settlers, many of whom are engaged in informal sector activities or part time work. The settlement has undergone several periods of rapid expansion, with most of these occurring just after significant flood and fire events. Natural and human induced disasters have therefore opened up opportunities for people to move in to and expand the settlement [41].

Quarry Road West informal settlement is located on the narrow floodplain of the Palmiet River, in close proximity to an extensive road network (Figure 1). Although the history of flooding is not well documented, due both to the recent history and lack of data recording in informal settings, there are various media accounts of the Palmiet River breaking its banks and causing flooding after heavy rainfall events [42]. The increasing intensity of storms, which is attributed to climate change, is escalating the flood risk in the settlement. The majority of residents in the settlement have migrated to Durban from the rural areas of KwaZulu-Natal and the Eastern Cape, and they retain strong links with their rural homes, participating in circular migration [43]. The settlement has four municipally provided Community Ablution Blocks (CABs) containing showers, toilets and wash basins. Residents have access to free basic water through communal standpipes.

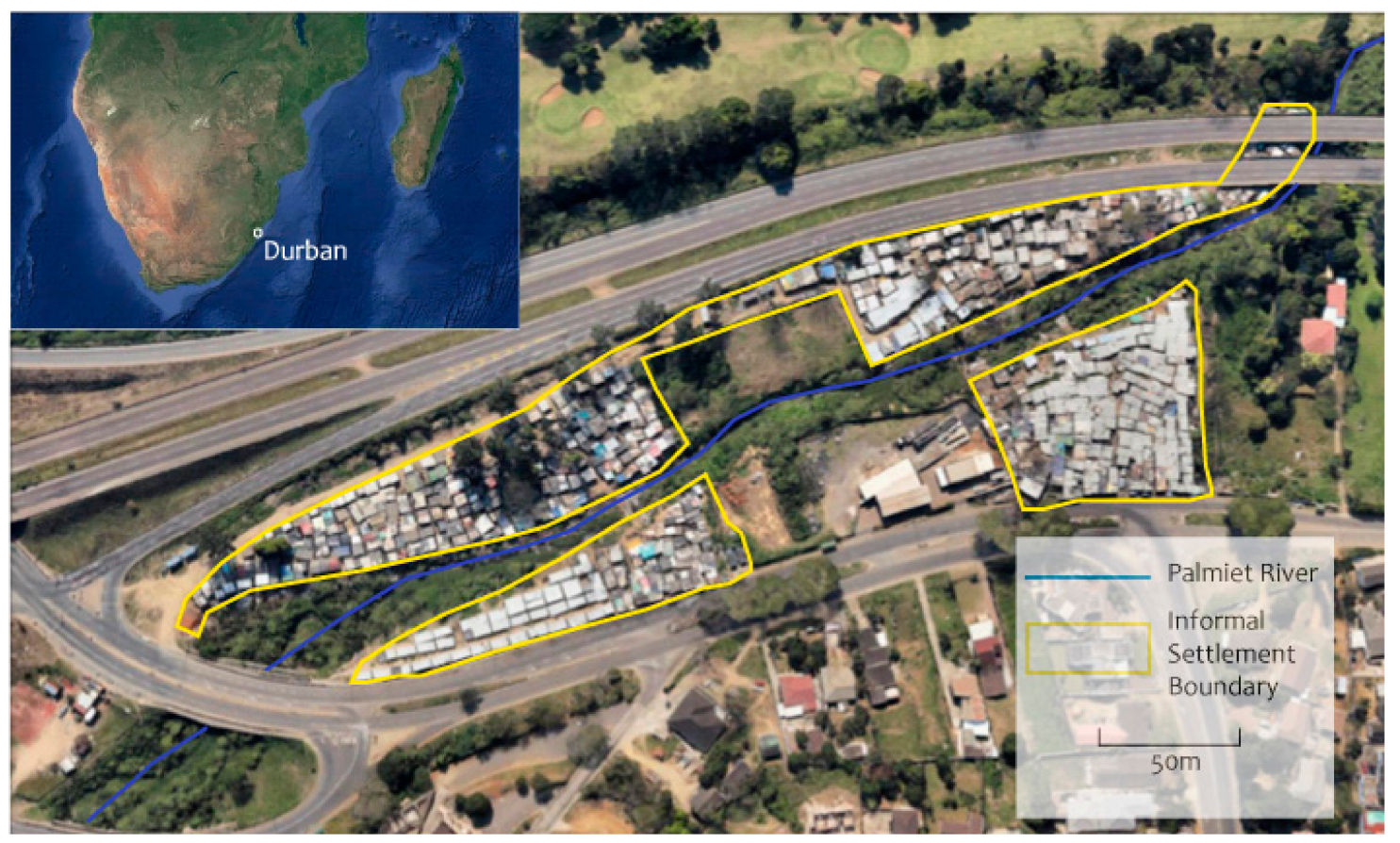

Figure 1. Four sections of Quarry Road West informal settlement intersected by the Palmiet River flowing from west to east. The location of Durban in the southern African context is illustrated in the

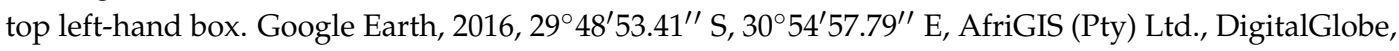
https:/ / earth.google.com [44].

In accordance with the HDA Act No. 23, 2008, the mandate to assist entities of the state with undertaking upgrading measures in informal settlements in Durban lies with the Housing Development Agency, a national public-sector agency implementing and managing the development of housing and human settlements $[36,45]$. Planning and project activities, such as impact assessment 
studies, land acquisition studies, architectural plans and engineering surveys, are carried out by eThekwini municipality [46]. The task of implementing infrastructural developments in informal settlements is then often subcontracted to consultants [46]. In trying to achieve a more coordinated planning approach, the Integrated Development Planning Process was devised, aiming at encouraging sustainable development and democratic priorities [47]. Observations however indicate that this has not been entirely successful, with a lack of policies dealing with spatial and socio-economic legacies of Apartheid, a considerable housing backlog, and an uncoordinated public policy [46,47]. Informal settlements are not adequately considered in or incorporated into urban planning, and there are few possibilities for affected communities to involve themselves in the planning process [46].

One of the aims of the PRP, the multi-sector partnership forming the focus of this assessment, is to work toward resolving this issue. The PRP is an innovative project which integrates water and climate governance in the Palmiet River Catchment in Durban, through a partnership between municipal officials, research institutions, community-based organizations and ordinary citizens [29,48]. The PRP forms part of the broader uMngeni Ecological Infrastructure Project (UEIP) which is a multi-actor governance network aiming to secure water resources in the uMngeni Catchment, a river basin which enables six million people to live and prosper in South Africa's third largest regional economy, by enhancing the value of ecological infrastructure [49]. In both the UEIP and the PRP, transdisciplinary research is being conducted to understand the relations between the multiple actors and socio-ecological, economic and political processes that constitute each catchment $[48,50]$. It represents a non-formal partnership of stakeholders with legislative powers predominantly vested in the municipality. Quarry Road West informal settlement reflects the challenges produced by the collective impact of both rapid urbanization in a context of poverty and significant housing and service backlogs in Durban, and the increasing climate-related risk as a result of climate change.

\section{Materials and Methods}

In an attempt to develop capacity for learning from the success and failure of integrative and transdisciplinary multi-sector partnerships through an evaluative process [13], the Capital Approach Framework was developed [22]. Conceptually based on the Capital Theory Approach, the Capital Approach to Sustainability, and the Capability Approach [22], it uses and utilizes the concept of capitals and their interlinkages with sustainability and governance performance [30]. Stipulating that livelihood opportunities are determined by livelihood assets, to which individuals and households have varying levels of access [51], the same principle can be applied to residents or communities exposed to climate-induced risk [22]. The livelihood assets are represented in human, political, financial, and environmental capitals. They are reconceptualized as such that they not only encompass the resources used by people, but rather determine the capability of multi-sector partnerships to act in the instance of risk [52]. The capitals are comprised of several factors, which are in turn measured by indicators, generating a measure of performance for each capital and establishing a governance baseline. The indicators are parameters for the effectiveness of the multi-sector partnership in the ability to face risk. In doing so, the strength of the capitals relates directly to the ability of multi-sector partnerships to respond and react in the face of climate-induced risk [22,53].

Social capital, the first of the five capitals in the framework, consists of social networks and trust, encompassing the confidence and faith shared between all actors in the decision-making and policy-planning process. This helps build a co-operative and social climate to work collectively towards a common goal $[22,54]$. Equitable treatment of all stakeholders in the entire decision-making and policy-planning process, as well as the possibility of collective, inclusive participation for all actors is a necessary prerequisite for successful cooperation in local governance [55]. Effective communication and information processes between actors also form the basis for successful multi-sector partnerships [22], as do strict rules and norms of society, notwithstanding formal and informal rules [22,56]. Acquired knowledge on the potential risks and perturbations are additional 
factors which, when taking cultural and historical contexts into account, can contribute substantively to increasing resilience [22,55].

Human capital links in with the concept of preparedness, principally influenced by knowledge through education [22]. Whether an environment for innovation is created, facilitating the implementation of creative ideas, and whether gender equality is promoted, are also important factors for productive cooperation and effective governance [54].

Political capital covers transparency and trust in political actions [22,55]. The amount and intensity of political protest, electoral participation and corruption are all indicators for transparency and trust in political actions. Political capital also includes a stable regulatory framework, ensuring disaster preparedness and facilitating response and recovery procedures [22].

Financial capital comprises of disaster funds allocated to provide both short- and long-term assistance to affected communities and individuals. These are essential in ensuring the delivery of public services and basic infrastructure, as well as helping to recover and rebuild after flooding has occurred. Financial capital also relates to the ability of combating the risk of impoverishment after a perturbation. Accounting for losses and damages, upon which economies and societies depend, is necessary for coping with natural hazards and preventing the fall into poverty traps [22,57].

Environmental capital includes the regeneration of the environment through measures taken by society once a natural hazard has occurred. It relates directly to ecosystem services, the protection of which can provide natural and sustainable protection, particularly from climate-induced risk. Management strategies and planning processes, including community-driven projects ensuring the protection of ecosystems, or legally binding frameworks, are also significant factors when considering environmental capital [22].

There are various social values embedded in the Capital Approach Framework, including the equal treatment of men and women, protecting the natural environment, equal treatment of, and trust between actors, and transparency and accountability. Integrating these social values into transdisciplinary local governance for water management can improve the effectiveness of multi-sector partnerships, further promising to reduce vulnerability to flood risk. This may also assist in prioritizing partnerships as a legitimate governance entity [27].

Each of social, human, political, financial and environmental capital consists of various factors, which in turn can be measured by indicators. The indicators represent the evaluative criteria necessary to assess both the outcomes and processes of achieving outcomes [58]. These indicators are thus qualitatively evaluated by the participants taking part in the study. The analysis is therefore based on the insights, knowledge, and perceptions of stakeholders involved in or affected by the multi-sector partnership, co-producing knowledge for assessing local governance for water management [30].

In the case of Quarry Road West informal settlement, 45 indicators were generated to assess the performance of local governance for water management (Table 1). The decision to generate 45 indicators is based on the number of indicators generated in previous applications of the Capital Approach Framework (those being 46, 45, 44, and 46) [22,30]. The indicators were in part based on previous participatory studies on local governance [30], and in part generated and adjusted to the local context by the authors of this research. Subsequently, questions were developed pertaining to each of the 45 indicators and gathered in a questionnaire. Questions pertained both to the performance of the PRP itself, and current state of local governance for water management in Quarry Road West informal settlement from the perception of PRP members [30], giving a holistic view of local governance for water management in Quarry Road West informal settlement. 
Table 1. List of capitals, factors and indicators forming part of the assessment of five capitals of local governance for water management in Quarry Road West informal settlement, Durban South Africa.

\begin{tabular}{|c|c|c|c|}
\hline Capital & Factor & No. & Indicator \\
\hline \multirow[t]{18}{*}{ Social Capital } & Equitable treatment of all partners & 1 & $\begin{array}{l}\text { Equal say in decision-making and policy-planning } \\
\text { process }\end{array}$ \\
\hline & Communication and Information & 2 & Access to historical databases \\
\hline & & 3 & Transparency of communication process \\
\hline & & 4 & Availability of reports in local languages \\
\hline & & 5 & Interpreters present at local meetings \\
\hline & Participation & 6 & Participation in public meetings \\
\hline & & 7 & Number of formal meetings per year \\
\hline & & 8 & Existence of monitoring processes \\
\hline & Knowledge & 9 & Educational programs open for participation \\
\hline & & 10 & Subject of risk discussed during program \\
\hline & & 11 & Understanding of regulatory framework \\
\hline & & 12 & Access to legal advice \\
\hline & Trust & 13 & Knowledge on influences of traditional beliefs \\
\hline & & 14 & $\begin{array}{l}\text { Number of years representatives stay the same, } \\
\text { fostering trust }\end{array}$ \\
\hline & & 15 & Previous examples of conflict resolution \\
\hline & Rules and norms of society & 16 & Creation of informal boards \\
\hline & & 17 & Amount of money donated after flood \\
\hline & & 18 & Volunteer mobilization \\
\hline \multirow[t]{3}{*}{ Human Capital } & Skills and competencies & 19 & Average level of education \\
\hline & Gender equality & 20 & Equal representation of men and women \\
\hline & Innovation & 21 & Creation of environment fostering innovation \\
\hline \multirow[t]{12}{*}{ Political Capital } & $\begin{array}{l}\text { Transparency and trust in political } \\
\text { actions }\end{array}$ & 22 & Political stability \\
\hline & & 23 & Absence of political protests \\
\hline & & 24 & Peacefulness of protests \\
\hline & & 25 & Election turnout \\
\hline & & 26 & Absence of political pressure \\
\hline & & 27 & Absence of corruption \\
\hline & & 28 & Transparency of decision-making process \\
\hline & & 29 & Trust in law-enforcement \\
\hline & $\begin{array}{l}\text { Regulatory framework: formal } \\
\text { rules and norms }\end{array}$ & 30 & $\begin{array}{l}\text { Laws in place to protect environment and facilitate } \\
\text { disaster management }\end{array}$ \\
\hline & & 31 & Creation of emergency plans \\
\hline & & 32 & Obligation to obtain insurance \\
\hline & & 33 & Creation of risk maps \\
\hline \multirow[t]{5}{*}{ Financial Capital } & Financial security & 34 & $\begin{array}{l}\text { Percentage of residents dependent on government } \\
\text { subsidies }\end{array}$ \\
\hline & & 35 & Access to loans/micro-credit \\
\hline & Disaster funds & 36 & Amount of disaster funds provided by government \\
\hline & Risk of impoverishment & 37 & Availability of compensation after flood event \\
\hline & & 38 & Quality of public services and basic infrastructure \\
\hline \multirow{7}{*}{$\begin{array}{l}\text { Environmental } \\
\text { Capital }\end{array}$} & Ecosystem services & 39 & Awareness of ecosystem services \\
\hline & & 40 & Reliance on ecosystem services \\
\hline & $\begin{array}{l}\text { Management strategies and } \\
\text { planning process }\end{array}$ & 41 & Legal frameworks binding \\
\hline & & 42 & $\begin{array}{l}\text { Community-based projects creating awareness of } \\
\text { ecosystem services }\end{array}$ \\
\hline & Regeneration of environment & 43 & Actions taken to regenerate environment after flood \\
\hline & & 44 & Differential land-use in the risk area \\
\hline & & 45 & Land protection \\
\hline
\end{tabular}

Each indicator was assigned a unit of measure and characterized as binary, ordinal or cardinal unit measure. The responses of the interviewees in turn were assigned a color according to their performance relating to the traffic-light system, green for positive responses, yellow for varied responses, and red for negative responses (see [22,30]). For example, to measure the "access to legal advice" indicator, interviewees were asked whether they were able to call upon legal advice to 
advise on regulatory matters. If the answer was "no", then the response would be assigned a red color. This indicator would then be used to measure the "Knowledge" factor, in turn used to assess Social Capital. Another example would be whether interviewees had the possibility of taking part in capacity building exercises, used to measure the "Human Resources" factor, in turn used to assess Human Capital. The answers given by each participant were then aggregated to form one value for each indicator. The strength of a capital is thus determined by whether the factors and indicators of the relevant capital, to which questions during the assessment pertained, received positive or negative responses, i.e., performed strongly or poorly.

A total of ten stakeholders, seven women and three men, with different sectoral backgrounds were selected in close collaboration with experts from the University of KwaZulu-Natal and a community member active in the PRP to represent each partner of the multi-stakeholder partnership. Five community members were chosen with sufficient knowledge and experience within the PRP and on flooding events in Quarry Road West informal settlement. Two members of a research team from the School of Built Environment and Development Studies at the University of KwaZulu-Natal (UKZN), working in partnership with the Quarry Road West informal settlement community since September 2014 with the aim of understanding and improving the relations between the community and the Palmiet River, were also selected. Furthermore, two representatives from the private sector involved in the PRP were consulted, along with one municipal officer from eThekwini Human Settlements Division involved in local decision-making and policy-planning.

In the case of the five community members, the questionnaires were presented and answered in a joint two-hour long session in close vicinity to the settlement. With the assistance of two interpreters, necessary due to the community members not speaking English, and the lack of IsiZulu knowledge on the part of the interviewer, each question was explained and answered individually. Questions pertaining to the profile of the interviewees, other than their employment in the informal sector, were not included in the questionnaire to protect their wish to remain anonymous. A comparatively high number of community members were included in the assessment due to the need to incorporate and amplify previously marginalized local knowledge and perceptions, which is essential when undertaking empirical work in informal settlements [50]. The other five questionnaires were sent and received electronically.

\section{Results}

The capital receiving the highest evaluation was human capital, followed by environmental, social, political, and financial capital, although the number of varied responses was larger here than in other cases. The assessment per indicator totaled for each capital is presented in Figure 2, with the percentage on the $y$-axis representing all the responses given by the interviewees. Please refer to Table A1 for a more detailed evaluation of each indicator, factor and capital.

The evaluation indicates that political and financial capital are the least effective in current local governance for water management. In accordance with the traffic-light assessment, positive responses indicating high effectiveness are highlighted in green, negative responses indicating low effectiveness in red, and varied responses indicating moderate effectiveness in yellow. 


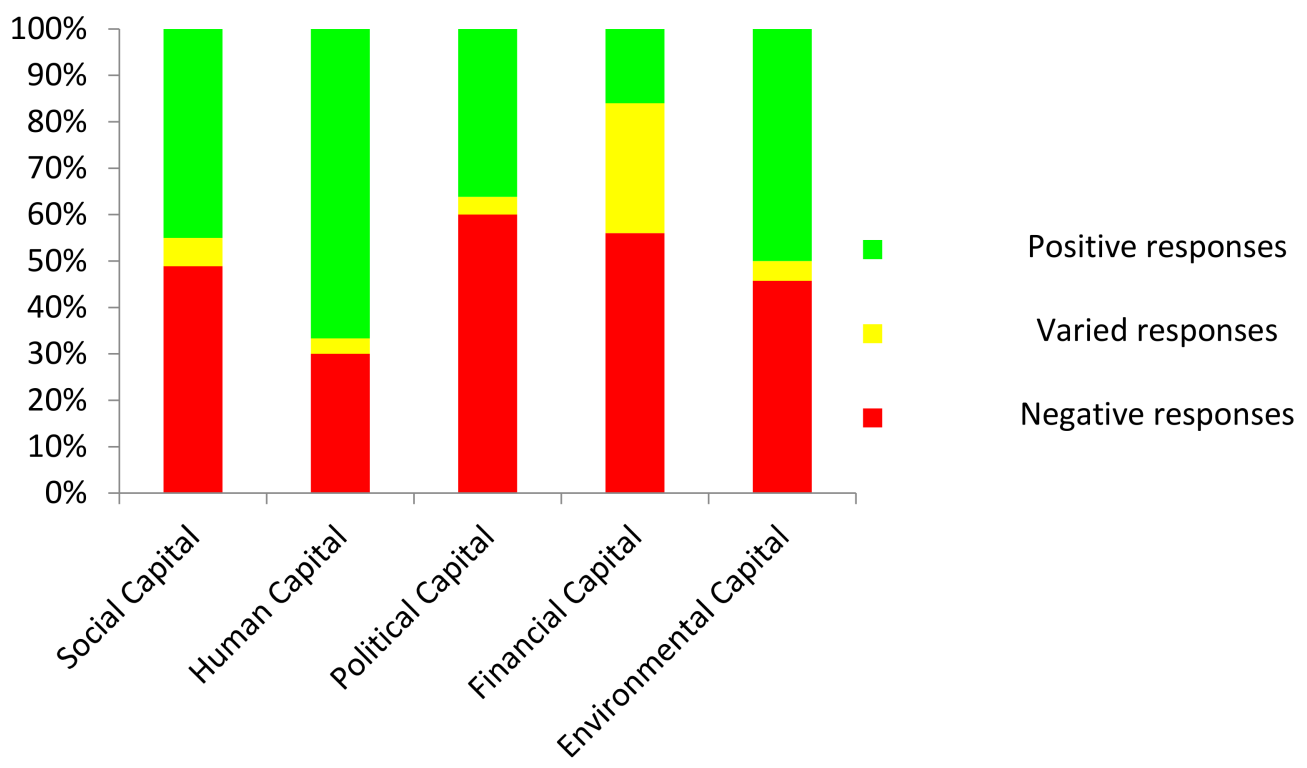

Figure 2. Results from the assessment of five capitals of local governance for water management in Quarry Road West informal settlement, Durban South Africa. Strength of each capital, with positive responses in green, varied in yellow and negative responses in red.

The capital achieving the highest-ranking factor and indicator evaluation was human capital (Figure 3a). The indicators "Gender equality" and "Innovation" received largely effective evaluation, revealing a common agreement both in relation to equal treatment of men and women, as well as in the creation of an environment for fostering innovation. The "skills and competencies" factor received varied responses due to the diverse levels of educational status within the PRP.

Environmental capital (Figure 3b) achieved a positive response rate of 50\%. This was largely down to the promotion of awareness and benefits that ecosystem services can provide, as well as the successful implementation of community-based programs creating awareness for and protecting ecosystem services by the PRP, bolstering the "Management" factor. The "Regeneration" of environment factor, pertaining to the amount of environmental regeneration after floods and differential land-uses and land protection, received a negative evaluation.

Social capital (Figure 3c) is the most detailed capital, consisting of 18 indicators and six factors. The only factor in the entire assessment to receive a score of $0 \%$ was the "Equitable treatment" indicator, revealing whether all stakeholders felt treated equally. However, scores for "Communication" and "Participation" factors were similarly poor. Social capital performed moderately well in the "Knowledge" factor, for which the existence of educational programs discussing the subject of risk run by the PRP contributed significantly. Results for the "Trust" factor were mainly negative, however not to the same degree as the first three factors. Responses to the "Rules and norms of society" factor were varied, a result of positive answers concerning the formation of informal boards, and negative answers concerning money donated and volunteers mobilized in the immediate aftermath of floods.

Receiving the second least amount of positive responses, and the highest amount of negative responses, was political capital (Figure 3d). The "Transparency" factor, mainly concerned with political actions, scored particularly low. Possible explanations are the presence of political instability, violent protests, political pressure, and corruption. There was a lack of understanding concerning the decision-making and policy-planning process, as well as low levels of trust in law enforcement. The "Regulatory framework" factor performed slightly higher due to laws and regulations in place to protect people from, and to help manage, natural disasters. Results do however point toward a lack of institutions for setting legal frameworks. Some respondents were aware of the creation of risk maps, 
however the challenge of obtaining insurance, let alone the obligation to acquire insurance, did not receive any positive responses.

Out of the five capitals, financial capital (Figure 3e) received the least amount of positive responses. A low proportion of inhabitants receiving subsidies and very limited access to official micro-loans, as well as a lack of funds made available in the wake of a disaster, resulted in low scores for the factors "Financial security" and "Disaster funds". The shortage of compensation for losses during floods and the low quality of public services and basic infrastructure further illustrates the danger of impoverishment.
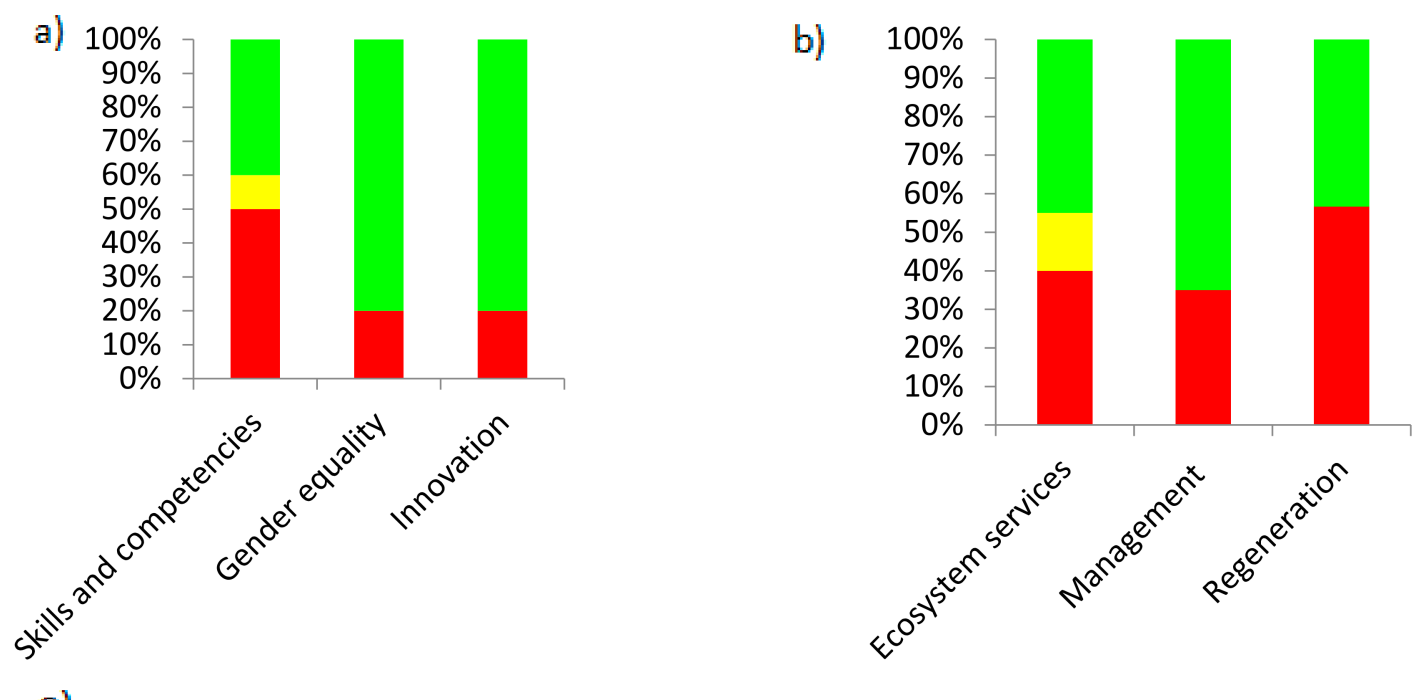

c)

d)
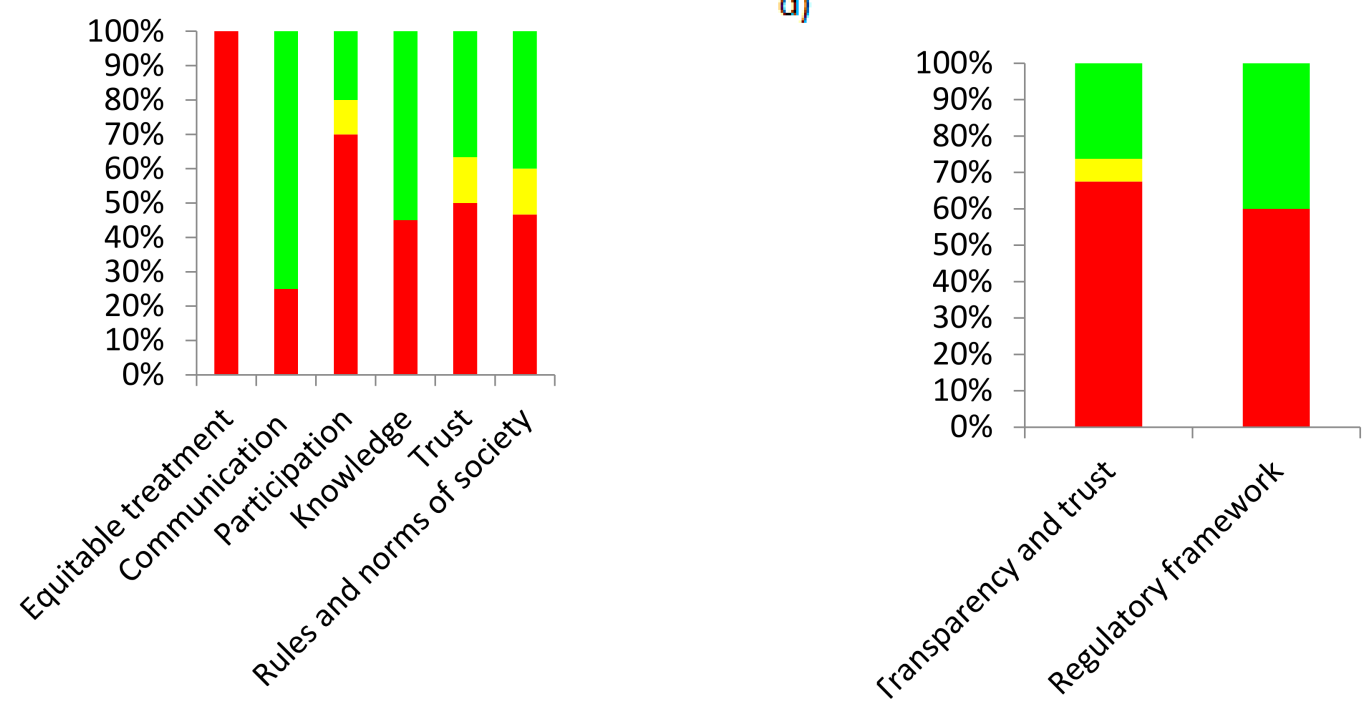

Figure 3. Cont. 
e)

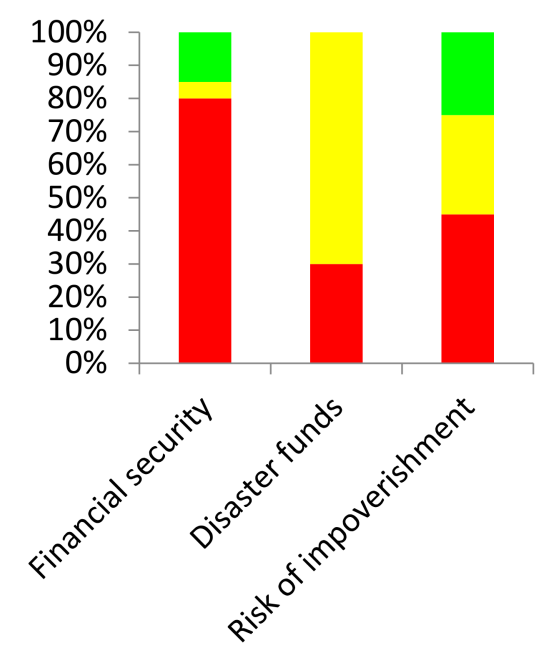

Figure 3. Assessment of the component factors of five capitals of local governance for water management in Quarry Road West informal settlement, Durban South Africa. Factors for each capital ranked from best to worst performing: (a) human capital; (b) environmental capital; (c) social capital; (d) political capital; and (e) financial capital. The assigned colors are according to performance relating to the traffic-light system: green for positive responses, yellow for varied responses, and red for negative responses.

\section{Discussion}

Enabling informal settlements to adapt to climate change impacts has to be treated as a priority [1]. During the evaluation however, it became clear the there was a disconnect between the community in Quarry Road West informal settlement and other sectors, with municipal authorities challenged by the priority actions required to enable adaptation to climate change. This was offset by high resourcefulness and efficiency of the local community, as well as the positive effect of the PRP on flood risk, confirming findings made in other regions $[1,30]$.

Results for human capital indicate an equal picture in terms of gender, a prerequisite essential for the prevention of marginalization in terms of participating in partnerships between communities and local governments [59]. The promotion of gender equality has been central to various institutions in post-Apartheid South Africa and appears to have been successful in the context of the PRP. While there is still the need for improvement at local governance level across South Africa, the results generated imply that women have access to power and resources while also being able to influence government policy, which is crucial for sustainable social and economic development [59]. Innovation, the cultivation and support of new methods, ideas and actions, is a further indicator for human capital, the fostering of which should be seen as a governance priority. Innovation can generally be enhanced by multi-sectoral network connectivity. Possibilities to interact with each other and to increase collaboration should therefore be supported and facilitated [60]. The results indicate that innovation is being fostered. One contributing factor is the creation of the PRP itself, driving community-led innovation processes for decreasing vulnerability to flooding, as well as improving the livelihoods of those living in Quarry Road West informal settlement. There is however still the need for improvement concerning skills and competencies of some members of the PRP.

"Management" is the strongest-performing factor within environmental capital. Again, the PRP plays a determining role here due to the implementation of community-based projects creating awareness for and protection of ecosystem services, a vital function for increasing resilience toward flooding [61]. The PRP not only provides knowledge for the municipality's action plans to rehabilitate the river, but also aim to improve water quality and alleviate flood risk through community-based projects such as paying for collected waste which can cause drainage blockages or organizing 
awareness-raising workshops. Emphasizing the importance of ecosystem services can facilitate more effective local governance for water management, whilst at the same time provide a range of socio-economic benefits [62]. The shift from "hard" to "soft" solutions through focusing on the social construction of water quality and environmental services further encourages the promotion of ecosystem-based adaptation [29]. Although the reliance on ecosystem services is seen as moderate in Quarry Road West informal settlement, the awareness of the importance of ecosystem services in general scored considerably higher. The factor "Regeneration" of the environment performed lowest within environmental capital due to the lack of provision for differential land-use and land protection, enhancing the impacts of flooding [63]. Land-use has shown to have a significant impact on floods, particularly in urban areas [64]. Land protection preventing the sealing off of natural drainage areas and restricting urbanization upstream can alleviate the risk of flooding downstream. Appropriate land-use management is critical to preserve the permeability of soils and to reduce run-off.

Concerning social capital, participants were united in their perception of stakeholders involved in the decision-making and policy-planning process being treated unequally. The fair treatment of all governance members is cited as a requirement for adaptive and integrative capacities [21], an element not recognized by interviewees with regard to Quarry Road West informal settlement. Together, these indicators determine the effectiveness of the "Participation" factor. Inclusion of affected communities in the initial phase of decision-making and policy-planning has shown to foster various dimensions of trust [65]. The democratic deficit in knowledge production, upon which decision-making and policy-planning in Quarry Road West informal settlement is currently based, calls for greater integration of perspectives, knowledge, and beliefs [19]. Participation of stakeholders in local governance for water management has shown to increase the effectiveness and acceptance of decisions and policies [19]. Overlooking social dimensions has in the past been a principle factor in the design of ineffective adaptation outcomes as they fail to connect with what matters to individuals and communities [65].

Closely linked to lack of participation are the rarity and irregularity of meetings in which all stakeholders are able to participate, as well as the lack of monitoring processes auditing potential progress. The lack of monitoring processes enforcing legislation is a key bottleneck in the implementation of flood adaptation [62]. The "Communication and information" factor also received negative responses, particularly concerning interactions between municipality representatives and inhabitants of Quarry Road West informal settlement. Few data concerning past flood events are accessible, transparency in communication is insufficient, and reports are rarely available in local languages. Access to knowledge, such as records of past flooding events, has shown to affect the personal ability to cope with flood risk [7]. Communities need to have access to and be able to process new knowledge [66]. Particularly when dealing with flood risk, the integration of climate knowledge for both decision-makers and policy-planners, as well as local communities has shown to be key in reducing vulnerability to climate-related risk, highlighting the need for a better understanding in the transfer of climate change knowledge depending on societal structures [67].

Trust, a vital predictor for the success of negotiations between stakeholders on decisions and actions [68], is a further factor in need of improvement. Although interviewees were able to recall some previous occasions when conflicts were resolved between themselves and other stakeholders on decisions and actions, successful conflict resolution remains a key governance challenge. Particularly in the informal context, continuity of governance members encourages effective conflict resolution and sustainable development [46]. Furthermore, traditional beliefs often influence local risk perception [69], and though there is knowledge of traditional beliefs in the risk area, the high rate of turnover of Municipality representatives and other stakeholders, as well as the few examples of successful conflict resolutions in the past, lead to this indicator receiving negative responses. The "Rules and norms of society" factor indicates the government's ability to implement policies, especially in the context of private sector development [22]. Although the creation of multi-stakeholder groups, such as the PRP, has contributed positively to this factor, the perceived lack of money donated and volunteers 
mobilized in the immediate aftermath of a flooding event, means the indicator still received mainly negative responses.

Political capital consisted of two factors that both performed poorly. There is a lack of transparency in political actions. Political protests, sometimes turning violent, are also commonplace in Quarry Road West informal settlement. Not only does this indicate societal unrest, but it also underlines the ineffectiveness of formal institutions, in turn affecting the application of laws and practices [62]. These are common characteristics of informal settlements [28]. The levels of political pressure and corruption reported by respondents confirm these attributes of a democratic deficit, further underlined by the low level of trust in law-enforcement. Respondents did however estimate a moderate election turnout among residents, indicating a perceived appetite for democratic participation. There was also moderate awareness of the creation of risk maps and emergency plans. Although there are laws in place to protect the environment and facilitate disaster management, the difficulties of implementing monitoring processes has already been discussed. Innovative legal frameworks are however necessary if projections of increasing complexities and uncertainties in relation to flood risk are to hold true [62].

Financial capital receiving the least positive responses confirms reflections on the inadequate financial framework for informal settlements in South Africa [70]. It reiterates widely held views that the financial frameworks in place perpetuate inequality and facilitate marginalization of the urban poor, enforcing socio-political control and patronage [70]. Low financial security, caused by lack of access to subsidies and micro-credit, heavily constrains adaptive capacity [71,72]. The lack of disaster funds provided by government, in the immediate aftermath of a flood, complete absence of insurance schemes, and insufficient funding for long-term risk reduction efforts such as appropriate landscape and urban planning, further increase the risk of impoverishment.

The Capital Approach Framework also provided insight into the integration of various social values into local governance for water management. Gender equality is integrated well into local governance, and stakeholders foster an environment of innovation and impetus. The community also values its natural surroundings, underlined by the high awareness in the importance of ecosystem services. Democratic participation, transparency and accountability however were not evaluated positively. There is a lack of trust, particularly between community members and the municipality, fueled by the perception that stakeholders involved in or affected by flooding in Quarry Road West informal settlement are not treated equally. Integrating these social values is critical in effective local governance for water management, and future actions would have to consider the potential synergies and interdependencies between them [66]. Trust is a key influence permeating throughout partnerships, influencing effective risk communication and the implementation of adaptation strategies [73]. Previous successful cooperation enhances the levels of trust [74], while mismanagement of climate-induced risk has shown to be a major factor in damaging the level of trust between communities, scientists, and decision-makers and policy-planners. Open dialogue with affected communities through democratic participation, fostering transparency and accountability, and promoting the importance of ecosystem services, needs to be encouraged.

Considerations need to be made for the negative effects some capitals may have on others, in particular citing the frequent destructive force of financial capital, most commonly being furthered to the detriment of environmental and social capital [52]. A too narrow focus on economic development to support financial capital has often damaged ecological infrastructure [62]. This could be particularly harmful in the context of informal settlements, as the financial security of residents is low [57]. The decision to invest in certain capitals therefore needs to be deliberated carefully with stakeholders. Considerations for their synergistic nature, both positive and negative, and the potential prioritization of certain capitals, must be made when identifying resilience-enhancing pathways, the next step in generating actionable information and in influencing policy debates [75]. Due to the need to heavily adapt the Capital Approach Framework according to the local context, there is no universal governance benchmark to compare results to. There is however the possibility of repeating the assessment at a 
later stage to compare results and track developments. This would also help in evaluating the effect of policy measures on the five capitals before and after implementation.

The PRP was commonly referred to by participants during the evaluation, particularly on occasions when factors were given a positive evaluation. This showcases the positive effect of the PRP on local governance for water management in Quarry Road West informal settlement. Through implementing community-based projects and raising awareness for the natural environment, the PRP has promoted the value of ecological infrastructure. Furthermore, the PRP has assumed the key role of mediator between residents of Quarry Road West informal settlement and the municipality, a relationship that has shown conflictual tendencies in the past. Transdisciplinary in nature, the PRP engages in both physical and social science research, adding to the positive influence of polycentric local governance in responding to flooding, and underlining the importance of strengthening the mechanisms and political influence of the PRP, and multi-sector partnerships in general [30,62], particularly in the context of informal settlements where institutionalism and mainstream governance are often neglected [1].

Since managing water-related risk is a responsibility commonly shared across various levels of governance leading to increased diffusion among societal actors, multi-sector partnerships have the potential to integrate social values and enact effective local governance for flood risk management through active participation and opportunity creation [76]. Effective local governance for water management has to be carried out by partnerships, and thus strengthening these partnerships may assist in reducing risk from floods. There are several steps to be considered when attempting to strengthen multi-sector partnerships [27]. Although devised principally for the transnational context, there are various steps applicable to this local multi-sector partnership. Actors need to show leadership for creating momentum and guiding the process of risk reduction, while at the same time fostering group cohesion. Precise goal-setting can help in creating common visions and goals, while enforcing values of transparency and inclusiveness. Setting minimum criteria for involvement, acknowledging differences between members, and engaging in designing according to problem structures, may not only strengthen the multi-sector partnership, but further enhance the adaptive capacity in local governance for water management [27].

The Sendai Framework for Disaster Risk Reduction cites the importance of inclusive risk assessments and land-use policy, calling for integrative and transdisciplinary approaches to deal with climate-induced risk [24]. This study contributes to implementing the Sendai Framework by promoting the importance of community integration and identifying the areas in need of improvement for achieving more effective local governance for water management. Developing concrete and specific guidance for decision-makers and policy-planners for improving the strength of the capitals is beyond the scope of this paper. However, it is important to acknowledge that the right to participation is even more essential when informal communities are involved, as these communities are commonly excluded from urban planning processes.

\section{Conclusions}

Researchers have argued for strengthening integrative and transdisciplinary partnerships between decision-makers and policy-planners, practitioners, and other stakeholders for improved management and knowledge co-production $[1,13]$. This paper argues that community participation is also essential for knowledge co-production in transdisciplinary and integrative forms of local governance for water management. This is of particular importance concerning previously marginalized communities residing in informal settlements across the Global South.

In applying the Capital Approach Framework, the five capitals offered an assessment of the ability of local government to adapt and respond to flood risk. A governance baseline was established, and strengths and weaknesses could be identified. Human capital received a positive evaluation, while political and financial capital are in most need of strengthening. The integration of several social values was also assessed, emphasizing the need for embedding these into local governance 
processes. Management measures to support not only political and financial capital, but all other capitals as well, whilst at the same time promoting social values, will need to be taken in consultation with all the necessary stakeholders to enhance local governance for water management and reduce flood risk. This governance baseline may serve as a reference point for analyzing the impact of future policy measures.

The Capital Framework returned an in-depth assessment of composite factors and indicators for that capital. This allows repeatability over time and the inclusion of governance as an important and measurable component of any assessment of progress against goals or targets such as national development goals, the United Nations Sustainable Development Goals, and many others.

The study further highlights the positive effect of the PRP on local governance, making the argument for acknowledging and prioritizing the PRP as a legitimate form of governance. The paper makes several suggestions for strengthening the PRP, which in turn would have a positive impact on the resilience of the residents of Quarry Road West informal settlement. The act of knowledge co-production can further facilitate the exchange of information and experiences. This is important for decision-makers and policy-planners, as there are many lessons for climate change adaptation which can be learned from informal communities with limited coping capacities.

Author Contributions: D.S.W., M.M.C., L.C., and C.S. conceived the methodological approach for this study. D.S.W. designed the assessment for the local context, carried out the analysis, analyzed the data and wrote the paper. All other authors assisted in each of these steps.

Acknowledgments: The authors would like to thank the reviewers for their invaluable comments, contributing significantly to the depth and meaningfulness of the paper. David Samuel Williams, María Máñez Costa, and Louis Celliers were funded by the KnowHow project under the European Commission Marie Curie IRSES Grant (PIRSES-GA-2013-612-615). The authors would further like to thank the European Union project Enhancing Risk Management Partnerships for Catastrophic Natural Hazards in Europe (ENHANCE) for support. Gratitude must also be extended to the Council for Scientific and Industrial Research (CSIR), who were the host organization. Finally, without the dedicated help and support of Sibongile Buthelezi and Duduzile Khumalo, both funded through the CLIMWAYS project of the National Research Foundation South Africa, this research would not have been possible.

Conflicts of Interest: The authors declare no conflict of interest.

\section{Appendix A}

Table A1. Detailed responses to each indicator, factor and capital.

\begin{tabular}{|c|c|c|c|c|c|c|}
\hline Factor & No. & $\begin{array}{l}\text { Indicator Related to } \\
\text { the Factor }\end{array}$ & $\begin{array}{l}\text { Evaluation } \\
\text { Criteria }\end{array}$ & & Assessment & \\
\hline & & & & $\begin{array}{l}\text { Positive } \\
\text { Response }\end{array}$ & $\begin{array}{l}\text { Moderate } \\
\text { Response }\end{array}$ & $\begin{array}{l}\text { Negative } \\
\text { Response }\end{array}$ \\
\hline \multicolumn{7}{|c|}{ Social Capital } \\
\hline $\begin{array}{l}\text { Equitable treatment } \\
\text { of all partners }\end{array}$ & 1 & $\begin{array}{l}\text { Equal say in decision-making } \\
\text { process }\end{array}$ & $\mathrm{Y} / \mathrm{N}$ & 0 & & 10 \\
\hline \multirow{3}{*}{$\begin{array}{l}\text { Communication } \\
\text { and Information }\end{array}$} & 2 & Access to historical databases & $\mathrm{Y} / \mathrm{N}$ & 3 & & 7 \\
\hline & 3 & $\begin{array}{c}\text { Transparency of } \\
\text { communication process }\end{array}$ & $\mathrm{Y} / \mathrm{N}$ & 2 & & 8 \\
\hline & 4 & $\begin{array}{c}\text { Availability of reports in local } \\
\text { languages }\end{array}$ & $\mathrm{Y} / \mathrm{N}$ & 3 & & 7 \\
\hline
\end{tabular}


Table A1. Cont.

\begin{tabular}{|c|c|c|c|c|c|c|}
\hline \multirow{3}{*}{ Participation } & 6 & $\begin{array}{l}\text { Participation in } \\
\text { public meetings }\end{array}$ & $\mathrm{Y} / \mathrm{N}$ & 2 & & 8 \\
\hline & 7 & $\begin{array}{l}\text { Number of formal meetings } \\
\text { per year }\end{array}$ & $>10 / 5-9 / 1-4$ & & 3 & 7 \\
\hline & 8 & $\begin{array}{c}\text { Existence of } \\
\text { monitoring processes }\end{array}$ & $\mathrm{Y} / \mathrm{N}$ & 3 & & 7 \\
\hline \multirow{4}{*}{ Knowledge } & 9 & $\begin{array}{l}\text { Educational programs open } \\
\text { for participation }\end{array}$ & $\mathrm{Y} / \mathrm{N}$ & 8 & & 2 \\
\hline & 10 & $\begin{array}{l}\text { Subject of risk discussed } \\
\text { during program }\end{array}$ & $\mathrm{Y} / \mathrm{N}$ & 6 & & 4 \\
\hline & 11 & $\begin{array}{l}\text { Understanding of } \\
\text { regulatory framework }\end{array}$ & $\mathrm{Y} / \mathrm{N}$ & 6 & & 4 \\
\hline & 12 & Access to legal advice & $\mathrm{Y} / \mathrm{N}$ & 2 & & 8 \\
\hline \multirow{3}{*}{ Trust } & 13 & $\begin{array}{l}\text { Knowledge on influences of } \\
\text { traditional beliefs }\end{array}$ & $\mathrm{Y} / \mathrm{N}$ & 6 & & 4 \\
\hline & 14 & $\begin{array}{l}\text { Number of years } \\
\text { representatives stay the same, } \\
\text { fostering trust }\end{array}$ & $>10 / 5-9 / 1-4$ & & 6 & 4 \\
\hline & 15 & $\begin{array}{l}\text { Previous examples of } \\
\text { conflict resolution }\end{array}$ & $\mathrm{Y} / \mathrm{N}$ & 5 & & 5 \\
\hline \multirow{3}{*}{$\begin{array}{l}\text { Rules and norms of } \\
\text { society }\end{array}$} & 16 & Creation of informal boards & $\mathrm{Y} / \mathrm{N}$ & 7 & & 3 \\
\hline & 17 & $\begin{array}{l}\text { Amount of money donated } \\
\text { after flood }\end{array}$ & $\begin{array}{l}\text { High/Moderate/ } \\
\text { Low }\end{array}$ & & 4 & 6 \\
\hline & 18 & Volunteer mobilization & $\mathrm{Y} / \mathrm{N}$ & 5 & & 5 \\
\hline \multicolumn{7}{|c|}{ Human Capital } \\
\hline $\begin{array}{l}\text { Skills and } \\
\text { competencies }\end{array}$ & 19 & Average level of education & $\begin{array}{l}\text { High/Moderate/ } \\
\text { Low }\end{array}$ & 4 & 1 & 5 \\
\hline Gender equality & 20 & $\begin{array}{l}\text { Equal representation of men } \\
\text { and women }\end{array}$ & $\mathrm{Y} / \mathrm{N}$ & 8 & & 2 \\
\hline Innovation & 21 & $\begin{array}{l}\text { Creation of environment } \\
\text { fostering innovation }\end{array}$ & $\mathrm{Y} / \mathrm{N}$ & 8 & & 2 \\
\hline \multicolumn{7}{|c|}{ Political Capital } \\
\hline \multirow{8}{*}{$\begin{array}{l}\text { Transparency and } \\
\text { political actions }\end{array}$} & 22 & Political stability & $\mathrm{Y} / \mathrm{N}$ & 4 & & 6 \\
\hline & 23 & Absence of political protests & $\mathrm{Y} / \mathrm{N}$ & 2 & & 8 \\
\hline & 24 & Peacefulness of protests & $\mathrm{Y} / \mathrm{N}$ & 3 & & 7 \\
\hline & 25 & Election turnout & $\begin{array}{l}>66 \% / 66-33 \% / \\
<33 \%\end{array}$ & 3 & 5 & 2 \\
\hline & 26 & Absence of political pressure & $\mathrm{Y} / \mathrm{N}$ & 3 & & 7 \\
\hline & 27 & Absence of corruption & $\mathrm{Y} / \mathrm{N}$ & 2 & & 8 \\
\hline & 28 & $\begin{array}{c}\text { Transparency of } \\
\text { decision-making process }\end{array}$ & $\mathrm{Y} / \mathrm{N}$ & 3 & & 7 \\
\hline & 29 & Trust in law-enforcement & $\mathrm{Y} / \mathrm{N}$ & 3 & & 7 \\
\hline \multirow{4}{*}{$\begin{array}{l}\text { Regulatory } \\
\text { framework: formal } \\
\text { rules and norms }\end{array}$} & 30 & $\begin{array}{l}\text { Laws in place to protect } \\
\text { environment and facilitate } \\
\text { disaster management }\end{array}$ & $\mathrm{Y} / \mathrm{N}$ & 6 & & 4 \\
\hline & 31 & Creation of emergency plans & $\mathrm{Y} / \mathrm{N}$ & 3 & & 7 \\
\hline & 32 & $\begin{array}{l}\text { Obligation to } \\
\text { obtain insurance }\end{array}$ & $\mathrm{Y} / \mathrm{N}$ & 0 & & 10 \\
\hline & 33 & Creation of risk maps & $\mathrm{Y} / \mathrm{N}$ & 5 & & 5 \\
\hline
\end{tabular}


Table A1. Cont.

\begin{tabular}{|c|c|c|c|c|c|c|}
\hline \multicolumn{7}{|c|}{ Financial capital } \\
\hline \multirow[t]{2}{*}{ Financial security } & 34 & $\begin{array}{l}\text { Percentage of residents } \\
\text { dependent on } \\
\text { government subsidies }\end{array}$ & $\begin{array}{l}<33 \% / 33-66 \% / \\
\quad>66 \%\end{array}$ & 2 & 1 & 7 \\
\hline & 35 & Access to loans/micro-credit & $\mathrm{Y} / \mathrm{N}$ & 1 & & 9 \\
\hline Disaster funds & 36 & $\begin{array}{l}\text { Amount of disaster funds } \\
\text { provided by government }\end{array}$ & $\begin{array}{l}\text { High/Moderate/ } \\
\text { Low }\end{array}$ & 0 & 6 & 4 \\
\hline \multirow{2}{*}{$\begin{array}{c}\text { Risk of } \\
\text { impoverishment }\end{array}$} & 37 & $\begin{array}{l}\text { Availability of compensation } \\
\text { after flood event }\end{array}$ & $\mathrm{Y} / \mathrm{N}$ & 3 & & 7 \\
\hline & 38 & $\begin{array}{l}\text { Quality of public services and } \\
\text { basic infrastructure }\end{array}$ & $\begin{array}{l}\text { High/Moderate/ } \\
\text { Low }\end{array}$ & 1 & 6 & 3 \\
\hline \multicolumn{7}{|c|}{ Environmental capital } \\
\hline \multirow{2}{*}{ Ecosystem services } & 39 & $\begin{array}{c}\text { Awareness of ecosystem } \\
\text { services }\end{array}$ & $\mathrm{Y} / \mathrm{N}$ & 6 & & 4 \\
\hline & 40 & $\begin{array}{l}\text { Reliance on ecosystem } \\
\text { services }\end{array}$ & $\begin{array}{l}\text { High/Moderate/ } \\
\text { Low }\end{array}$ & 4 & 2 & 4 \\
\hline \multirow{2}{*}{$\begin{array}{l}\text { Management } \\
\text { strategies and } \\
\text { planning process }\end{array}$} & 41 & Legal frameworks binding & $\mathrm{Y} / \mathrm{N}$ & 4 & & 6 \\
\hline & 42 & $\begin{array}{l}\text { Community-based projects } \\
\text { creating awareness of } \\
\text { ecosystem services }\end{array}$ & $\mathrm{Y} / \mathrm{N}$ & 9 & & 1 \\
\hline \multirow{3}{*}{$\begin{array}{l}\text { Regeneration of } \\
\text { environment }\end{array}$} & 43 & $\begin{array}{l}\text { Actions taken to regenerate } \\
\text { environment after flood }\end{array}$ & $\mathrm{Y} / \mathrm{N}$ & 4 & & 6 \\
\hline & 44 & $\begin{array}{l}\text { Differential land-use in the } \\
\text { risk area }\end{array}$ & $\mathrm{Y} / \mathrm{N}$ & 4 & & 6 \\
\hline & 45 & Land protection & $\mathrm{Y} / \mathrm{N}$ & 5 & & 5 \\
\hline
\end{tabular}

\section{References}

1. Bai, X.; Dawson, R.; Ürge-Vorsatz, D.; Delgado, G.; Barau, A.; Dhakal, S.; Dodman, D.; Leonardsen, L.; Masson-Delmotte, V.; Roberts, D.; et al. Six research priorities for cities and climate change. Nature 2018, 555, 23-25. [CrossRef] [PubMed]

2. United Nations Development Programme. 2018. Available online: http://www.undp.org/content/ undp/en/home/blog/2018/our-cities-are-on-the-frontline-of-changing-climate-html (accessed on 10 March 2018).

3. International Institute for Environment and Development. Available online: https://www.iied.org/ introduction-urban-poverty (accessed on 1 June 2018).

4. Nelson, J.M. Effects of participation by the poor. In Access to Power: Politics and the Urban Poor in Developing Nations; Nelsen, J.M., Ed.; Princeton University Press: Princeton, NJ, USA, 2017; ISBN 978-0-691-60588-3.

5. International Institute for Environment and Development. Available online: https://citiesipcc.org/wpcontent/uploads/2018/03/Informality-background-paper-for-IPCC-Cities.pdf (accessed on 25 April 2018).

6. Pachauri, R.K.; Meyer, L.A. Climate Change 2014: Synthesis Report. Contribution of Working Groups I, II, and III to the Fifth Assessment Report of the Intergovernmental Panel on Climate Change; IPCC: Geneva, Switzerland, 2014.

7. Kellens, W.; Terpstra, T.; De Maeyer, P. Perception and communication of flood risks: A systematic review of empirical research. Risk Anal. 2013, 33, 24-49. [CrossRef] [PubMed]

8. Diaz, H.P.; Hurlbert, M. The need for adaptive water governance: Lessons from Canada and Chile. In Climate Change Governance; Knieling, J., Filho, W.L., Eds.; Springer: Heidelberg, Germany, 2013; ISBN 978-3-642-29831-8.

9. Jha, A.; Boch, R.; Lamond, J. Cities and Flooding: A Guide to Integrated Urban Flood Risk Management for the 21st Century; World Bank Publications: Washington, DC, USA, 2012.

10. Wehn, U.; Rusca, M.; Evers, J.; Lanfranchi, V. Participation in flood risk management and the potential of citizen observatories: A governance analysis. Environ. Sci. Policy 2015, 48, 225-236. [CrossRef]

11. Hirabayashi, Y.; Mahendran, R.; Koirala, S.; Konoshima, L.; Yamazaki, D.; Watanabe, S.; Kim, H.; Kanae, S. Global flood risk under climate change. Nat. Clim. Chang. 2013, 3, 816-821. [CrossRef] 
12. Hope, K.R. Climate change and poverty in Africa. Int. J. Sustain. Dev. World Ecol. 2009, 16, 451-461. [CrossRef]

13. Pahl-Wostl, C.; Lebel, L.; Knieper, C.; Nikitina, E. From applying panaceas to mastering complexity: Toward adaptive water governance in river basins. Environ. Sci. Policy 2012, 23, 24-34. [CrossRef]

14. Grantham Research Institute on Climate Change and the Environment. Available online: http:/ / www.lse.ac.uk/GranthamInstitute/wp-content/uploads/2016/11/The-Global-Climate-LegislationStudy_2016-update.pdf (accessed on 3 January 2018).

15. Rosendo, S.; Celliers, L.; Mechisso, M. Doing more with the same: A reality-check on the ability of local government to implement integrated coastal management for climate change adaptation. Mar. Policy 2018, 87, 29-39. [CrossRef]

16. Surminski, S.; Aerts, J.; Alexander, D.; Di Bucci, D.; Mechler, R.; Mysiak, J.; Wilkinson, E. Prevention and mitigation: Avoiding and reducing the new and existing risks. In Science for Disaster Risk Management 2017: Knowing Better and Losing Less; Poljanšek, K., Marín Ferrer, M., De Groeve, T., Clark, I., Eds.; Publications Office of the European Union: Luxembourg, 2017; pp. 444-502.

17. Shah, A.; Shah, S. The new vision of local governance and the evolving roles of local governments. J. Public Admin. 2009, 3, 1-46.

18. Sendai Framework for Disaster Risk Reduction. Available online: https://www.unisdr.org/we/inform/ publications / 43291 (accessed on 1 March 2018).

19. Krueger, T.; Maynard, C.; Carr, G.; Bruns, A.; Mueller, E.N.; Lane, S. A transdisciplinary account of water research. Wiley Interdiscip. Rev. Water 2016, 3, 369-389. [CrossRef] [PubMed]

20. Ward, P.J.; Pauw, W.P.; Van Buuren, M.W.; Marfai, M.A. Governance of flood risk management in a time of climate change: The cases of Jakarta and Rotterdam. Environ. Polit. 2013, 22, 518-536. [CrossRef]

21. Renn, O.; Klinke, A.; van Asselt, M. Coping with complexity, uncertainty and ambiguity in risk governance: A synthesis. Ambio 2011, 40, 231-246. [CrossRef] [PubMed]

22. Máñez Costa, M.; Carmona, C.; Gerkensmeier, B. Assessing Governance Performance; Report 20; Climate Service Centre Germany: Hamburg, Germany, 2014.

23. Aerts, J.; Mysiak, J. Novel Multi-Sector Partnerships in Disaster Risk Management; Enhance Project: Brussel, Belgium, 2017.

24. United Nations Strategy for Disaster Risk Reduction. 2015. Available online: https:/ /www.unisdr.org/files / 43291_sendaiframeworkfordrren.pdf (accessed on 26 February 2018).

25. Türkkahraman, M. Social values and value education. Procedia Soc. Behav. Sci. 2014, 116, 633-638. [CrossRef]

26. Pahl-Wostl, C.; Gupta, J.; Petry, D. Governance and the global water system: A theoretical exploration. Glob. Gov. Rev. Multilater. Int. Organ. 2008, 14, 419-435. [CrossRef]

27. Pattberg, P.; Widerberg, O. Transnational multi-stakeholder partnerships for sustainable development. Ambio 2016, 45, 42-51. [CrossRef] [PubMed]

28. Braathen, E.; Dupont, V.; Jordhus-Lier, D.; Sutherland, C. Situating the politics of slums within the 'urban turn'. In The Politics of Slums in the Global South; Dupont, V., Jordhus-Lier, D., Sutherland, C., Braathen, E., Eds.; Routledge: London, UK, 2016; ISBN 978-1-138-83981-6.

29. Vogel, C.; Scott, D.; Culwick, C.E.; Sutherland, C. Environmental problem-solving in South Africa: Harnessing creative imaginaries to address 'wicked' challenges and opportunities. S. Afr. Geogr. J. 2016, 98, 515-530. [CrossRef]

30. Carmona, M.; Máñez Costa, M.; Andreu, J.; Pulido-Velazquez, M.; Haro-Monteagudo, D.; Lopez-Nicolas, A.; Cremades, R. Assessing the effectiveness of Multi-Sector Partnerships to manage droughts: The case of the Jucar river basin. Earth's Future 2017. [CrossRef]

31. Beisheim, M.; Liese, A. (Eds.) Transnational Partnerships: Effectively Providing for Sustainable Development? Springer: Heidelberg, Germany, 2014; ISBN 978-1-137-35953-7.

32. Dodman, D.; Mitlin, D. Challenges for community-based adaptation: Discovering the potential for transformation. J. Int. Dev. 2013, 25, 640-659. [CrossRef]

33. Reid, H.; Alam, M.; Berger, R.; Cannon, T.; Huq, S.; Milligang, A. Community-based adaptation to climate change: An overview. Particip. Learn. Act. 2009, 60, 11-33.

34. eThekwini Municipality. Available online: https://www.durban.gov.za/City_Government/City_Vision/ IDP/Documents/Final\%202014_15\%20IDP.pdf (accessed on 25 February 2018). 
35. Roberts, D.; O'Donoghue, S. Urban environmental challenges and climate change action in Durban, South Africa. Environ. Urban. 2013, 25, 299-319. [CrossRef]

36. Housing Development Agency. Available online: https://www.thehda.co.za/uploads/files/HDA_ KwaZulu-Natal_Report_lr.pdf (accessed on 15 January 2018).

37. World Bank. Available online: documents.worldbank.org/curated/en/312921468184169809/pdf/103643WP-p148662-PUBLIC-Durban-Ethekwini-Urb-Env-Profile-A4-v2.pdf (accessed on 17 January 2017).

38. eThekwini Municipality. Available online: http://www.durban.gov.za/City_Services/energyoffice/ Documents/DCCS_Final-Draft\%20(4).pdf (accessed on 28 April 2018).

39. EThekwini Municipality. Available online: https://www.bbhub.io/mayors/sites/14/2015/06/DurbanAction-Plan.pdf (accessed on 22 April 2018).

40. Climate Service Center Germany. Available online: http://www.climate-service-center.de/cms21/finder/ index.php.en?topics=0\&continents=Africa\&countries=80_62 (accessed on 22 April 2018).

41. Sutherland, C.; Scott, D.; Hordijk, M. Urban water governance for more inclusive development: A reflection on the 'waterscapes' of Durban, South Africa. Eur. J. Dev. Res. 2015, 27, 488-504. [CrossRef]

42. IOL News. Available online: https://www.iol.co.za/news/south-africa/kwazulu-natal/shacks-floodedafter-downpour-1970489 (accessed on 17 April 2018).

43. Posel, D.; Marx, C. Circular migration: A view from destination households in two urban informal settlements in South Africa. J. Dev. Stud. 2013, 49, 819-831. [CrossRef]

44. Google Earth. Available online: https:/ / earth.google.com (accessed on 1 June 2017).

45. Housing Development Agency. Available online: http://thehda.co.za (accessed on 25 February 2018).

46. Patel, K. A successful slum upgrade in Durban: A case of formal change and informal continuity. Habitat Int. 2013, 40, 211-217. [CrossRef]

47. United Nations Habitat. The Challenge of Slums: Global Report on Human Settlements Earthscan; United Nations Habitat: London, UK, 2003; ISBN 1-84407-037-9.

48. Sutherland, C.; O'Donoghue, S.; Sim, V.; Khuzwayo, Z.; D'Eathe, L. Developing innovative governance approaches for climate and water resilience at the local scale: A case study of the Palmiet Rehabilitation Project, Durban, South Africa. In Proceedings of the Nordic Conference, Bergen, Norway, 20-23 August 2017.

49. Institute of Natural Resources. Available online: http://inr.org.za/wp-content/uploads/2014/06/uMngeniHandbook.pdf (accessed on 21 March 2018).

50. Sutherland, C. City Profile. In The Politics of Slums in the Global South; Dupont, V.D., Jordhus-Lier, D., Sutherland, C., Braathen, E., Eds.; Routledge: London, UK, 2016; ISBN 978-1-138-83981-6.

51. Serrat, O. The sustainable livelihoods approach. In Knowledge Solutions; Serrat, O., Ed.; Springer: Singapore, 2017; ISBN 978-981-10-0983-9.

52. Bebbington, A. Capitals and capabilities: A framework for analyzing peasant viability, rural livelihoods and poverty. World Dev. 1999, 27, 2021-2044. [CrossRef]

53. Busby, J.W.; Smith, T.G.; White, K.L.; Strange, S.M. Locating climate insecurity: Where are the most vulnerable places in Africa? In Climate Change, Human Security and Violent Conflict; Scheffran, J., Brzoska, M., Brauch, H.G., Link, P.M., Schilling, J., Eds.; Springer: Heidelberg, Germany, 2012; ISBN 978-3-642-28625-4.

54. Brocklesby, M.A.; Fisher, E. Community development in sustainable livelihoods approaches-An introduction. Community Dev. J. 2003, 38, 185-198. [CrossRef]

55. Tanner, T.; Mitchell, T.; Polack, E.; Guenther, B. Urban governance for adaptation: Assessing climate change resilience in ten Asian cities. IDS Work. Pap. 2009, 209, 1-47. [CrossRef]

56. Goodwin, N.R. Five Kinds of Capitals: Useful Concepts for Sustainable Development; Working Paper No. 3-7; Global Development and Environment Institute: Medford, OR, USA, 2003.

57. Jorgensen, R.; Rice, J.; Clark, B. Cities, slums, and energy consumption in less developed countries, 1990 to 2005. Organ. Environ. 2010, 23, 189-204. [CrossRef]

58. Ostrom, E. Background on the institutional analysis and development framework. Policy Stud. J. 2011, 39, 7-27. [CrossRef]

59. McEwan, C. 'Bringing government to the people': Women, local governance and community participation in South Africa. Geoforum 2003, 34, 469-481. [CrossRef]

60. Björk, J.; Magnusson, M. Where do good innovation ideas come from? Exploring the influence of network connectivity on innovation idea quality. J. Prod. Innov. Manag. 2009, 26, 662-670. [CrossRef] 
61. Davids, R.; Rouget, M.; Boon, R.; Roberts, D. Identifying ecosystem service hotspots for environmental management in Durban, South Africa. Bothalia 2016, 46, 1-18. [CrossRef]

62. Pahl-Wostl, C.; Vörösmarty, C.; Bhaduri, A.; Bogardi, J.; Rockström, J.; Alcamo, J. Towards a sustainable water future: Shaping the next decade of global water research. Curr. Opin. Environ. Sustain. 2013, 5, 708-714. [CrossRef]

63. Helbron, H.; Schmidt, M.; Glasson, J.; Downes, N. Indicators for strategic environmental assessment in regional land use planning to assess conflicts with adaptation to global climate change. Ecol. Indic. 2011, 11, 90-95. [CrossRef]

64. Rogger, M.; Agnoletti, M.; Alaoui, A.; Bathurst, J.C.; Bodner, G.; Borga, M.; Chaplot, V.; Gallart, F.; Glatzel, G.; Hall, J.; et al. Land-use change impacts on floods at the catchment scale-Challenges and opportunities for future research. Water Resour. Res. 2017, 53, 5209-5219. [CrossRef] [PubMed]

65. Adger, W.N.; Barnett, J.; Brown, K.; Marshall, N.; O’brien, K. Cultural dimensions of climate change impacts and adaptation. Nat. Clim. Chang. 2013, 3, 112. [CrossRef]

66. Pahl-Wostl, C. Transitions towards adaptive management of water facing climate and global change. Water Resour. Manag. 2007, 21, 49-62. [CrossRef]

67. Dilling, L.; Lemos, M.C. Creating usable science: Opportunities and constraints for climate knowledge use and their implications for science policy. Glob. Environ. Chang. 2011, 21, 680-689. [CrossRef]

68. Rousseau, D.M.; Sitkin, D.; Burt, R.S.; Camerer, C.F. Not so different after all: A cross-discipline view of trust. Acad. Manag. Rev. 1998, 23, 393-404. [CrossRef]

69. Sjöberg, L.; Wåhlberg, A.A. Risk perception and new age beliefs. Risk Anal. 2002, 22, 751-764. [CrossRef] [PubMed]

70. Huchzermeyer, M. A legacy of control? The capital subsidy for housing, and informal settlement intervention in South Africa. Int. J. Urban Reg. Res. 2003, 27, 591-612. [CrossRef]

71. Folke, C.; Carpenter, S.; Elmqvist, T.; Gunderson, L.; Holling, C.S.; Walker, B. Resilience and sustainable development: Building adaptive capacity in a world of transformations. AMBIO J. Hum. Environ. 2002, 31, 437-440. [CrossRef]

72. Brooks, N.; Adger, W.N.; Kelly, P.M. The determinants of vulnerability and adaptive capacity at the national level and the implications for adaptation. Glob. Environ. Chang. 2005, 15, 151-163. [CrossRef]

73. Haynes, K.; Barclay, J.; Pidgeon, N. The issue of trust and its influence on risk communication during a volcanic crisis. Bull. Volcanol. 2008, 70, 605-621. [CrossRef]

74. Van de Meene, S.J.; Brown, R.R.; Farrelly, M.A. Towards understanding governance for sustainable urban water management. Glob. Environ. Chang. 2011, 21, 1117-1127. [CrossRef]

75. Collste, D.; Pedercini, M.; Cornell, S.E. Policy coherence to achieve the SDGs: Using integrated simulation models to assess effective policies. Sustain. Sci. 2017, 12, 921-931. [CrossRef]

76. Tortajada, C. Water governance: Some critical issues. Int. J. Water Resour. Dev. 2010, 26, 297-307. [CrossRef] 